\title{
THYROID STORM IN PREGNANCY
}

\author{
Rima Hayyu Chrisnanda, Sidarti Soehita \\ Department of Clinical Pathology, Faculty of Medicine, Airlangga University/Dr. Soetomo Hospital, Surabaya, Indonesia. \\ E-mail: rima.hayyu88@gmail.com
}

\begin{abstract}
Hyperthyroidism complicating pregnancy is a rare and threatening case. The incidence is about two cases in 1,000 pregnancies. A 33-year-old female, 32-33 weeks pregnant was admitted with shortness of breath since two days before hospitalization. She also suffered from vaginal bleeding, headache, nausea, and palpitation and was diagnosed with hyperthyroidism since three years ago, but the medication was uncontrolled. Physical examination: body temperature $37.7^{\circ} \mathrm{C}$, heart rate $170 \mathrm{x} /$ minute, respiratory rate $40 \mathrm{x} /$ minute and blood pressure 150/90 $\mathrm{mmHg}$, and no goiter. Laboratory result: Hemoglobin $10.6 \mathrm{~g} / \mathrm{dL}$, WBC 2.39 x 103/uL, and albumin $2.8 \mathrm{~g} / \mathrm{dL}$, AST $1.162 \mathrm{IU} / \mathrm{L}$, ALT $154 \mathrm{IU} / \mathrm{L}, \mathrm{FT} 4$ > $30 \mathrm{ng} / \mathrm{dL}$, TSH $0.0008 \mu \mathrm{IU} / \mathrm{mL}$ and T3 $6.3 \mathrm{ng} / \mathrm{mL}$, Procalcitonin $8.57 \mathrm{ng} / \mathrm{mL}$ and proteinuria + 3. ECG: sinus tachycardia. Burch Wartofsky score was 55. Blood Gas Analysis: pH 7.13, pCO2 33mmHg, pO2 174 mmHg, HCO3 -11 mmol/L, BEecf -18.2 mmol/L. Chest X-Ray: opacities on both lungs. At the time, her fetus was still alive. She was admitted to the ICU and treated with aggressive medical therapy. On the next day, she lost consciousness, and no fetal heart was detected. Decided to induce labor if Burch Wartofsky score $<25$. On the third day, the condition worsened, and the next day she passed away due to septic shock. Based on the physical examination and the laboratory results, the patient was diagnosed with a thyroid storm with preeclampsia and pneumonia. Uncontrolled maternal hyperthyroidism in pregnancy may cause thyroid storm, IUFD, and preeclampsia.
\end{abstract}

Key words: Thyroid storm, maternal hyperthyroidism, thyroid function, hyperthyroidism

\section{INTRODUCTION}

The prevalence of hyperthyroidism in pregnancy is about $0.5-2 / 1000$ pregnancies. The incidence of maternal and neonatal morbidity is significantly higher in those patients with uncontrolled hyperthyroidism. Female with hyperthyroidism who are under poor medical supervision have a higher incidence of thyroid storm. Maternal morbidity includes a high incidence of toxemia, premature delivery, placental abruption, congestive heart failure, and thyroid crisis. ${ }^{1}$ Hyperthyroidism does not often arise for the first time in early pregnancy, but clinicians need to be aware of the clinical sign and symptoms. ${ }^{2}$

\section{CASE}

A 33-year-old female at 32-33 weeks gestation (GIIIP2002) was admitted with shortness of breath since two days before hospitalization. She also suffered from vaginal bleeding, headache, nausea, and palpitation. There was no sign of rupture of the membranes. She was diagnosed as hyperthyroidism since three years ago, consumed tyrosol and methyl prednisolone but did not control routinely controlled. There was no history of hypertension.

From the physical examination, the patient was weak, and the GCS was 4-5-6. Vital signs were as follows; temperature $37.7^{\circ} \mathrm{C}$, heart rate $170 \mathrm{x} /$ minute, respiratory rate $40 \mathrm{x} /$ minute, and blood pressure $150 / 90 \mathrm{mmHg}$. Head and neck examination showed dyspnea, and no goiter was seen. Heart examination showed a single sound of S1-S1, no murmur. Lung examination showed the vesicular sound with rhonchi on both lungs but no wheezing. Abdominal examination showed no abnormality. The extremities were warm on both sides, but there was pitting edema on the lower extremities. The Burch Wartofsky score was 55 (Table 1 ).

Table 1. Burch Wartofsky score

\begin{tabular}{lc}
\hline & Score \\
\hline Temp $\left(37.2^{\circ} \mathrm{C}\right)$ & 5 \\
CNS & 0 \\
GI tract (nausea) & 10 \\
HR $(170 \times /$ minute $)$ & 25 \\
CHF (edema on both legs) & 5 \\
AF & 0 \\
Precipitating factors (pregnancy, & 10 \\
discontinuation of therapy) & \\
Total & 55 \\
\hline
\end{tabular}


At the time, her fetus was still alive. With a presumptive diagnosis of thyroid storm, she was admitted to the ICU and treated with aggressive medical therapy. The laboratory results showed leukocytosis, anemia, and albumin level was decreased. Meanwhile, the serum electrolytes were normal. Thyroid test function was increased. Liver enzymes were increased. Blood gas analysis showed an uncompensated metabolic acidosis. Chest X-Ray showed infiltration on both lungs. Electrocardiography showed sinus tachycardia. The patient was diagnosed as thyroid crisis, suspected lung edema, and hypoalbuminemia.

Two days later, she lost consciousness. No fetal heart was detected, and it was decided to induce labor if the Burch Wartofsky was < 25. The laboratory results showed leukocytosis, anemia, and albumin level was decreased. Meanwhile, the serum electrolytes were normal (Table 2, Figure 1).

On the third day, the condition worsened. Vital signs were as follows; temperature $39 \mathrm{C}$, heart rate $100 \mathrm{x} /$ minute, respiratory rate $38 \mathrm{x} /$ minute, and blood pressure $40 / 20 \mathrm{mmHg}$. On the next day, she passed away due to septic shock (Table 3).

Table 2. Laboratory result day 1

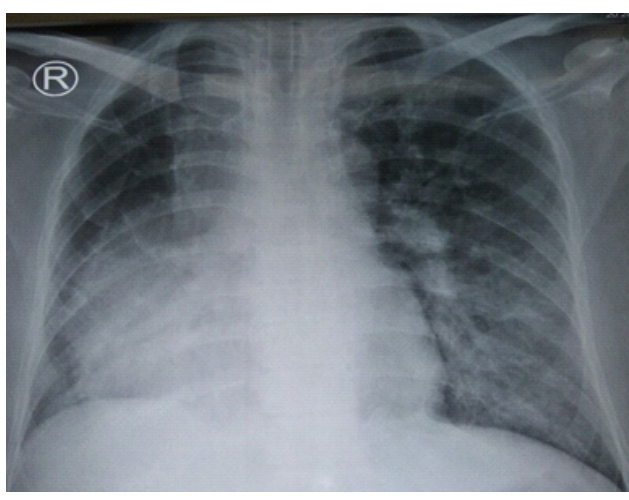

Figure 1. Chest X-Ray

\section{DISCUSSION}

A normal pregnancy results in a number of important physiological and hormonal changes that alter thyroid function. These changes mean that laboratory tests of thyroid function must be interpreted with caution during pregnancy. Thyroid function tests change during pregnancy due to the influence of two main hormones: human chorionic gonadotropin (hCG), the hormone that is measured in the pregnancy test and estrogen, the main female hormone. ${ }^{3}$

\begin{tabular}{|c|c|c|c|}
\hline Hematology & & Immunology & \\
\hline $\mathrm{Hb}(\mathrm{g} / \mathrm{dL})$ & 10.6 & $\mathrm{HBsAg}$ & Nonreactive \\
\hline $\mathrm{RBC}(X 10$ 6/uL) & 4.10 & FT4 (ng/dL) & 4.35 \\
\hline Hct $\%$ & 32.7 & T3 (ug/dL) & 6.3 \\
\hline $\operatorname{MCV}(f l)$ & 79.7 & $\mathrm{TSH}(\mathrm{UIU} / \mathrm{mL})$ & 0.0008 \\
\hline $\mathrm{MCH}(\mathrm{pg})$ & 25.8 & РСТ (ng/mL) & 1.61 \\
\hline $\mathrm{MCHC}(\mathrm{g} / \mathrm{dL})$ & 32.4 & Urinalysis & \\
\hline RDW (\%) & 14 & Glucose & Negative \\
\hline WBC (x $103 / \mathrm{uL})$ & 23.970 & Bilirubin & - \\
\hline Neu (\%) & 95.4 & Keton & Trace \\
\hline Lym (\%) & 0.86 & Urobilinogen & $16 \mathrm{mmol} / \mathrm{L}$ \\
\hline Mono (\%) & 0.14 & SG & 1.016 \\
\hline Baso (\%) & 0.3 & Protein & +3 \\
\hline Eos (\%) & 0.1 & Erythrocytes & Negative \\
\hline PLT (X 10 3/uL) & 217 & Leucocytes & +2 \\
\hline \multicolumn{2}{|l|}{ Clinical chemistry } & Nitrite & + \\
\hline BUN (mg/dL) & 38 & Color & Orange \\
\hline \multirow[t]{2}{*}{$\mathrm{SCr}(\mathrm{mg} / \mathrm{dL})$} & 3.2 & & \\
\hline & & Blood gas analysis & \\
\hline Potassium (mmol/L) & 4.5 & $\mathrm{pH}$ & 7.13 \\
\hline Sodium (mmol/L) & 139 & $\mathrm{pCO} 2(\mathrm{mmHg})$ & 33 \\
\hline Chloride (mmol/L) & 101 & $\mathrm{pO} 2(\mathrm{mmHg})$ & 174 \\
\hline Albumin $(\mathrm{g} / \mathrm{dL})$ & 2.8 & $\mathrm{HCO} 3(\mathrm{mmol} / \mathrm{L})$ & 11 \\
\hline AST (IU/L) & 1162 & BEecf (mmol/L) & -18.2 \\
\hline ALT (IU/L) & 154 & SO2 (\%) & 99 \\
\hline Glucose (mg/dL) & 119 & $\mathrm{TCO} 2(\mathrm{mmol} / \mathrm{L})$ & 12 \\
\hline
\end{tabular}


Table 3. Laboratory result day three

\begin{tabular}{|c|c|c|c|}
\hline Hematology & & Immunology & \\
\hline $\mathrm{Hb}(\mathrm{g} / \mathrm{dL})$ & 9.0 & PCT (ng/mL) & 8.57 \\
\hline $\operatorname{RBC}\left(\times 10^{6} / \mathrm{uL}\right)$ & 3.44 & Clinical chemistry & \\
\hline Hct \% & 28.8 & Potassium (mmol/L) & 5 \\
\hline $\operatorname{MCV}(\mathrm{fl})$ & 83.2 & Sodium (mmol/L) & 140 \\
\hline $\mathrm{MCH}(\mathrm{pg})$ & 25.8 & Chloride(mmol/L) & 100 \\
\hline $\mathrm{MCHC}(\mathrm{g} / \mathrm{dL})$ & 24.7 & Albumin (g/dL) & 2.8 \\
\hline RDW (\%) & 14 & & \\
\hline WBC $\left(\times 10^{3} / \mathrm{uL}\right)$ & 18.680 & Blood gas analysis & \\
\hline Neu (\%) & 74.2 & $\mathrm{pH}$ & 7.08 \\
\hline Lym (\%) & 8.7 & $\mathrm{pCO} 2(\mathrm{mmHg})$ & 34 \\
\hline Mono (\%) & 5.5 & $\mathrm{pO} 2(\mathrm{mmHg})$ & 46 \\
\hline Baso (\%) & 0.3 & $\mathrm{HCO} 3(\mathrm{mmol} / \mathrm{L})$ & 10 \\
\hline Eos (\%) & 0.1 & BEecf (mmol/L) & -19.9 \\
\hline $\operatorname{PLT}\left(X 10^{3} / \mathrm{uL}\right)$ & 230 & SO2 (\%) & 61 \\
\hline & & TCO2 (mmol/L) & 11 \\
\hline
\end{tabular}

Table 4. Thyroid hormones during pregnancy ${ }^{4}$

\begin{tabular}{llll}
\hline & $\mathbf{1}^{\text {st }}$-trimester & $\mathbf{2}^{\text {nd }}$-trimester & $\mathbf{3}^{\text {rd }}$-trimester \\
\hline TSH & Normal or decrease & Normal & Normal \\
Free T4 & Increase & Slightly decrease & Slightly decrease \\
Free T3 & Increase & Slightly decrease & Slightly decrease \\
Treg & Increase & Decrease & Slightly decrease \\
Tab & Decrease & Decrease & Decrease \\
\hline
\end{tabular}

TSH: Thyroid Stimulating Hormone; fT4: free T4; fT3: free T3; Treg: T regulatory cells; Tab: Thyroid Autoantibodies

The placenta produces Human Chorionic Gonadotropin (hCG) in the first week after conception, and the level is the highest at week ten before it begins to decrease and reaches a plateau at week 20. The hCG and TSH molecules share similarities, as do the receptors of hCG and TSH. ${ }^{4}$

Human chorionic gonadotropin can slightly increase the thyroid hormone and the high circulating hCG levels in the first trimester may result in a slightly low TSH (called subclinical hyperthyroidism). When this occurs, the TSH will be slightly decreased in the first trimester and then return to normal throughout pregnancy. Estrogen increases the amount of thyroid hormone binding proteins in the serum which increases the total thyroid hormone levels in the blood since $>99 \%$ of the thyroid hormones in the blood are bound to these proteins. The thyroid is functioning normally if the $\mathrm{TSH}$, Free T4, and Free T3 are all normal throughout pregnancy (Table 4). ${ }^{3}$

The Burch-Wortofsky point scale has been widely used as a device of diagnostic criteria for thyroid strom (Table 5$)^{5}$
Thyroid storm is a rare, life-threatening endocrinology emergency that can lead to cardiac arrest and death. A total of $20 \%$ to $30 \%$ of all cases are fatal. Patients can have a wide range of signs and symptoms. Females with untreated or poorly controlled thyrotoxicosis have a higher incidence of pre-eclampsia, heart failure, fetal loss, premature labor, and having a low birthweight baby than in those receiving adequate treatment. ${ }^{6}$

Thyroid storm can be precipitated by surgery, infection, trauma, or delivery. ${ }^{7.8}$ Patients with thyroid storm require assessment and management in an intensive care unit where they can be monitored for cardiac status, fluid and electrolyte balance, and control of hyperthermia. ${ }^{9}$ The underlying cause of thyroid storm must be identified and treated. Although patients who have already been treated for hyperthyroidism may have received antithyroid drugs, had surgery, or had radioiodine therapy and be euthyroid (whether receiving thyroxine or not), neonatal hyperthyroidism may still occur. ${ }^{10}$

Serious maternal, fetal, and neonatal morbidity and mortality are associated with uncontrolled 
Table 5. Burch and Wartofsky score (diagnostic criteria for thyroid storm) ${ }^{5}$

\begin{tabular}{|c|c|}
\hline Diagnostic Parameters & Scoring Points \\
\hline \multicolumn{2}{|c|}{ Thermoregulatory dysfunction (temperature in Fahrenheit) } \\
\hline 99-99.9 & 5 \\
\hline 100-100.9 & 10 \\
\hline 101-101.9 & 15 \\
\hline 102-102.9 & 20 \\
\hline 103-103.9 & 25 \\
\hline$>104$ & 30 \\
\hline \multicolumn{2}{|l|}{ Central nervous system effects } \\
\hline Absent & 0 \\
\hline Mild (agitation) & 10 \\
\hline Moderate (delirium, psychosis, extreme lethargy) & 20 \\
\hline Severe (seizure, coma) & 30 \\
\hline \multicolumn{2}{|l|}{ Gastrointestinal-hepatic dysfunction } \\
\hline Absent & 0 \\
\hline Moderate (diarrhea, nausea/vomiting, abdominal pain) & 10 \\
\hline Severe (unexplained jaundice) & 20 \\
\hline \multicolumn{2}{|l|}{$\begin{array}{l}\text { Cardiovascular function } \\
\text { Tachycardia (beats/minute) }\end{array}$} \\
\hline 90-109 & 5 \\
\hline 110-119 & 10 \\
\hline $120-129$ & 15 \\
\hline$>130$ & 25 \\
\hline \multicolumn{2}{|l|}{ Congestive heart failure } \\
\hline Absent & 0 \\
\hline Mild (pedal edema) & 5 \\
\hline Moderate(bibasilar rhales) & 10 \\
\hline Severe (pulmonary edema) & 15 \\
\hline \multicolumn{2}{|l|}{ Atrial fibrillation } \\
\hline Absent & 0 \\
\hline Present & 10 \\
\hline \multicolumn{2}{|l|}{ Precipitating event } \\
\hline Absent & 0 \\
\hline Present & 10 \\
\hline
\end{tabular}

BWPS $\geq 45$ is highly suggestive of thyroid storm; consider rapid and aggressive multimodal management in ICU.

BWPS 25-44 suggests impending thyroid storm; consider thionamides, symptom management. Consider ICU monitoring. BWPS $<25$ is unlikely to represent thyroid storm; investigate diagnosis of thyrotoxicosis (Graves's disease, toxic adenoma, toxic multinodular goiter, subacute thyroiditis, exogenous levothyroxine, struma ovarii) and obtain additional imaging (thyroid ultrasound, radioactive iodine uptake, and scan). ${ }^{5}$

hyperthyroidism. Maternal complications include miscarriage, pregnancy-induced hypertension, preterm labor, placental abruption, heart failure, and thyroid storm. Fetal and neonatal complications include stillbirth, low birth weight, goiter, hyperthyroidism, and hypothyroidism. ${ }^{11}$

Sepsis is a systemic response to infections in the body which can develop into severe sepsis and septic shock. Severe sepsis and septic shock are health problems and can cause death. Septic shock is defined as a sepsis condition with refractory hypotension: systolic blood $<90 \mathrm{mmHg}$, mean arterial pressure $<65 \mathrm{mmHg}$, or decrease $>40 \mathrm{mmHg}$ from the pressure threshold, and this condition is not responsive after the crystalloid fluid is given at 20 up to $40 \mathrm{~mL} / \mathrm{kg}^{12}$

To determine the extent of a person's organ function in septic condition, SOFA score can be used. The sequential organ failure assessment score, previously known as the sepsis-related organ failure assessment score (Table 6). ${ }^{13}$

In response to inflammation, acute infection, and 
Table 6. SOFA score ${ }^{12}$

\begin{tabular}{|c|c|c|c|c|c|}
\hline & 0 & 1 & 2 & 3 & 4 \\
\hline $\begin{array}{l}\text { Respiration } \\
\mathrm{PaO} 2 / \mathrm{FIO} 2 \\
\mathrm{mmHg}(\mathrm{kPa})\end{array}$ & $\geq 400$ & $<400$ & $<300$ & $\begin{array}{l}<200 \\
\text { (with } \\
\text { respiration } \\
\text { support } \\
\text { instrument) }\end{array}$ & $\begin{array}{l}<100 \\
\text { (with } \\
\text { respiration } \\
\text { support } \\
\text { instrument) }\end{array}$ \\
\hline $\begin{array}{l}\text { Coagulation } \\
\text { Platelet, } \times 10^{3} / \mathrm{uL}\end{array}$ & $\geq 150$ & $\geq 150$ & $<100$ & $<50$ & $<20$ \\
\hline $\begin{array}{l}\text { Liver Bilirubin, } \\
\mathrm{mg} / \mathrm{dL}\end{array}$ & $<1.2$ & $1.2-1.9$ & $2.0-5.9$ & $6.0-11.9$ & $>12.0$ \\
\hline Cardiovascular & $\begin{array}{l}\text { MAP } \\
\geq 70 \mathrm{mmHg}\end{array}$ & $\begin{array}{l}\text { MAP } \\
<70 \mathrm{mmHg}\end{array}$ & $\begin{array}{r}\text { Dopamin }<5 \\
\text { /dobutamine } \\
(\mathrm{ug} / \mathrm{kg} / \mathrm{min})\end{array}$ & $\begin{array}{l}\text { Dopamin 5.1- } \\
15 \text { /epinefrin } \\
\geq 0.1 / \text { no } \\
\text { repinefrin } \geq 0.1 \\
\text { (ug/ } \mathrm{kg} / \mathrm{min} \text { ) }\end{array}$ & $\begin{array}{l}\text { Dopamin }>15 \\
\text { /epinephrine } \\
>0.1 / \mathrm{no} \\
\text { repinefrin > } 0.1 \\
\text { (ug/kg/min) }\end{array}$ \\
\hline Glasglow coma & 15 & $13-14$ & $10-12$ & $6-9$ & $<6$ \\
\hline $\begin{array}{l}\text { Score Kidney } \\
\text { Creatinin, mg/dL }\end{array}$ & $<1.2$ & $1.2-1.9$ & $2.0-3.4$ & $3.5-4.9$ & $>5.0$ \\
\hline
\end{tabular}

Organ dysfunction is diagnosed if SOFA scores $\geq 2$

trauma, the number of leucocytes will increase, and in some diseases, such as sepsis, the increase in leucocytes is very high. Neutrophils react within an hour of tissue injury and are the hallmark of acute inflammation. An excessive increase in neutrophils (>50 $\times 109 / L)$ as a reactive phenomenon is known as a leukemoid reaction. When immature neutrophils are released, this is called left shift. ${ }^{14}$

Procalcitonin will increase in 4-12 hours as a response to a pro-inflammatory stimulus. The half-life of procalcitonin is about 22-35 hours and will not increase significantly with viral or non-infectious inflammations. Procalcitonin levels in the blood can highly increase and correlate with disease severity. ${ }^{15}$

The actual mechanism of production of procalcitonin during infection is unknown, but it assumes that bacterial lipopolysaccharides and sepsis released cytokines modulate the liver and peripheral blood mononuclear cells to produce procalcitonin. Procalcitonin is helpful for early detection of sepsis as well as to monitor the antimicrobial treatment regimen. ${ }^{16}$

\section{CONCLUSION}

Based on the clinical sign, history of past illness, high level of FT4 and T3, low level of TSH Burch Wartofsky score and the urinalysis (proteinuria $3+$ ), the patient was diagnosed as thyroid storm with pre- eclampsia. From the hematology result (leucocytosis), high level of procalcitonin, and SOFA score, the patient was also diagnosed with septic shock. Careful control and management of hyperthyroidism and sepsis could reduce the risk for IUFD and mortality in this patient

\section{REFERENCES}

1. Mestman JH. Hyperthyroidism in pregnancy. Clin Obstet Gynecol, 1997; 40(1): 45-64.

2. Marx H, Lazarus PA. Hyperthyroidism and pregnancy. Centre of Endocrine and Diabetes Sciences, University Hospital of Wales, Cardiff. BMJ, 2008; 336: 336-7.

3. Cignini P, Cafa E, Giorlandino C, Capriglione S, Spata A, Dugo N. Thyroid physiology, and common disease in pregnancy: Review of literature. Journal of Prenatal Medicine, 2012; 6(4): 64-71

4. Gaberscek S, Zaletel, K. Thyroid physiology and autoimmunity in pregnancy and after delivery. Expert Reviews of Clinical Immunology, 2011; 7(5): 697-707.

5. Burch. Burch-Wartofsky Point Scale (BWPS) for thyrotoxicosis. 2005. Accessed at www.mdcalc.com/ burch-wartofsky-point-scale-bwps-thyrotoxicosis.

6. Polak M, Le Gac I, Vuillard E, Guibourdenche J, Leger J, Toubert ME, et al. Fetal and neonatal thyroid function in relation to maternal Graves' disease. Best Pract Res Clin Endocrinol Metab, 2014; 18: 289-302.

7. Mandel SJ, Brent GA, Larsen PR. Review of antithyroid drugs during pregnancy and report of a case of aplasia cutis. Thyroid, 1994; 4: 129-33.

8. Weetman AP. Graves'disease. N Engl J Med, 2002; 343: 1236-48. 
9. Anselmo J, Cao D, Karrison T, Weiss RE, Refetoff S. Fetal loss associated with excess thyroid hormone exposure. JAMA, 2004; 292: 691-5.

10. Laurberg P, Nygaard B, Glinoer D, Grussendorf M, Orgiazzi J. Guidelines for TSH-receptor antibody measurements in pregnancy: Results of an evidencebased symposium organized by the European Thyroid Association. Eur J Endocrinol, 1998; 139: 584-90.

11. Millar LK, Wing DA, Leung AS, Koonings PP, Montoro $\mathrm{MN}$, Mestman JH. Low birth weight and preeclampsia in pregnancies complicated by hyperthyroidism. Obstet Gynecol, 1994; 84(6): 946-9.

12. Irvan Febyan, Suparto. Sepsis dan tata laksana berdasar guideline terbaru. Jurnal Anestesiologi Indonesia, 2018; 62-72.
13. Singer $M$, Deutschman CS, Seymour CW, Shankar-Hari $M$, Annane $D$, et al. The third international consensus definitions for sepsis and sepsis and septic shock. JAMA, 2016; 801.

14. Fraser T, Tilyard M. Complete blood count in primary care. BPAC Better Medicine, 2008; 5-9.

15. Reinhart K, Karzai W, Meisner M. Procalcitonin as a marker of the systemic inflammatory response to infection. Intensive Care Medicine. 2000; 26(9): 1193-200.

16. Vijayan AL, Vanimaya, Ravindran S, Siaikant R, Lakshmi $\mathrm{S}$, et al. Procalcitonin: A promising diagnostic marker for sepsis and antibiotic therapy. J Intensive Care, 2017; 5: 51 . 